searching for these hairs. In the course of my travels I have ever found it unwise to laugh at what I conceived to be the prejudices of a people simply because I could not understand them. In this instance, however, I must confess the results were not worth the trouble I took. The hairs, such as I picked up, and such as were shown me by the Chinese, had certainly been produced above the earth and not below it. In some instances they might readily be traced to horses, dogs, and cats, while in others they were evidently of vegetable origin. The northeastern part of China produces a very valuable tree known by the name of the hemp-palm [Chamarops Fortunei, see Kew Report, I880, p. 3I], from the quantity of fibrous bracts it produces just under its blossoms. Many of these fibres were shown to me by the Chinese as a portion of the hairs in question; and when 1 pointed out the source from which such had come, and which it was impossible to dispute, my friends laughed, and, with true Chinese politeness, acknowledged I was right, and yet I have no doubt they still held their former opinions concerning the origin of such hairs. The whole matter simply resolves itself into this: if the hairs pointed out to me were the true ones, then such things may be gathered not only after earthquakes, but at any other time. But if, after all, these were not the real things, and if some vegetable (I shall not say animal) production was formed, owing to the peculiar condition of the atmosphere and from other causes, I can only say that such production did not come under my observation." ${ }^{1}$

W. 'T. THISELTON DYER

\section{THE U.S. GEOLOGICAL SURVEY}

THE American papers contain an announcement which will be received with some astonishment in Europe. A member of Congress, Mr. Herbert, of Alabama, has introduced a Bill into the House prohibiting the Geological Survey of the United States from expending any money for palæontological work, except for the collection, classification, and proper care of fossils and other material ; and from composing, compiling, or preparing for publication monographs, bulletins, or other books except an annual report containing merely the transactions of the bureau and other routine official matter. It is further proposed to sell off the laboratories and other property of the Survey which after the passing of the Act would be no longer needed. Of course there may be official or departmental reasons for reorganisation or retrenchment of which the outside world is ignorant. But these reasons must be very serious indeed to justify such action as is proposed. If there is one scientific undertaking of which the United States have pre-eminently just reason to boast as a model to all civilised countries, it is their Geological Survey. For completeness of equipment it has no rival in the world, and already though it has only been seven years in existence its work both for excellence and amount has placed it in the very front of the scientific organisations of the time. Whether we look to its purely scientific achievements or to the importance of its practical work in mining and other economical departments, the crippling of the resources of the Geological Survey of the United States would be a calamity against which not only all lovers of science but all who are interested in the continued development of the natural productions of the great republic would energetically protest. We can hardly suppose that Mr. Herbert will have many supporters, and it is difficult to conceive from what possible motive he is acting. He calculates that if his Bill passes he will effect a saving of 250,000 dollars. He should try to find some branch of the public service where economy and retrench-

I " During a recent visit to the North-West Provinces of India, where earthquakes are not unfrequent, I could find no traditions such as that I
have alluded to." ment could be practised without seriously injuring the scientific credit and industrial progress of his country. And no doubt he could succeed in this search.

\section{THE ROYAL SOCIETY SOIRÉE}

THE President and Council of the Royal Society are to be entirely congratulated on the success of the reunion at Burlington House on the 12 th inst. It was generally felt that the display of objects of interest was finer than any brought together for some years, and the general satisfaction expressed must have amply rewarded those upon whom the burden of the arrangements had fallen.

It is a little hazardous to say which was the most interesting object; but as an actualité the unpaired parietal eye of Sphenodon exhibited by Mr. Baldwin Spencer, fully described in last week's NATURE, perhaps bore the palm.

Next in biological interest came an exhibit by Mr. W. $\mathrm{H}$. Caldwell including a complete series of the Ceratodus from the unsegmented egg to hatching. The complete exhibit illustrated early stages in development of the Monotremata-Ornithorhynchus and Echidna, the Dipnoid Ceratodus and some marsupial genera. The series were as follows:-

(I) Series of early stages of Ornithorhynchus, from a few hours after fertilisation to the newly-laid egg, of about the stage of a 36 -hour chick; (2) series of early stages of Echidna, from just before laying to the newly-hatched fœtus ; (3) various stages of young Echidna, from hatching up to 5 inches long ; (4) complete series of Ceratodus, from the unsegmented egg to hatching; (5) stages of young Ceratodus after hatching; (6) series of about thirty stages, from segmenting egg up to birth of Phascolarctos cinereus; (7) ditto of Halmaturus rufus; (8) Specimens showing the arrangement of the embryonic membranes in Macropus major.

There were two exhibits of micro-organisms--one of micro-photographs of Bacteria, and another of certain micro-organisms themselves-by Mr. Cheshire. The former included enlargements, from negatives obtained with an oil immersion $\frac{1}{25}$ inch, of the following :-

Anthrax-bacillus, in tissue-sections and cultivations; hay. bacillus ; bacillus of malignant œedema; micrococcus of pneumonia; tubercle-bacillus; bacillus of foul brood; Bacillus megatherium; Clostridium polymyxa; microbe of chicken cholera; comma-bacilli of Koch, Lewis, and Tinkler; Bacteria of putrefaction.

Mr. Cheshire exhibited (I) Bacillus alvei in sporulation ; (2) Bacillus alvei spores in chain ; and (3) spermatozoa of Apis forming in flocculent masses for packing in spermatophore.

Preparations illustrating the histological structure of the secretory tissues of certain plants, in which the substances secreted are of economic importance, were exhibited by Mr. W. Gardiner. Among these were hairs. of leaf of Flemingia Grahamiana-wurras dye ; laticiferous vessels of the stem of Manihot Glaziovii--ceara rubber ; glands of the leaf of Cinnamomum Camphora-camphor.

In connection with biological inquiry may be specially mentioned Mr. Frank Crisp's demonstration of a new microscopic object-glass, by Prof. Abbe of Jena, an exhibit rich in hope not only for the future of microscopy, but also for astronomy. Eight of the ten lenses of this objective are made of a new kind of optical glass, composed of phosphates and borates without silex. The glass hitherto used contains as essential components only six chemical elements, while the new objective contains not less than fourteen. The secondary spectrum is by this means entirely removed, and only a small tertiary spectrum remains. The improvement in definition is especially marked 